\title{
LOW TECHNOLOGICAL BIOLOGICAL TREATMENT OF SOURCE SEPARATED WASTE IN A BIOCELL
}

\author{
Janne H. Jarstad ${ }^{1}$ \\ L. Semb Vestgarden ${ }^{1}$ \\ B. E. Berg ${ }^{2}$ \\ ${ }^{1}$ Telemark University College, Dep. Environmental and Health Studies, Norway \\ ${ }^{2}$ GLT-Waste IKS, Norway
}

\begin{abstract}
In 2009 the Norwegian government banned biodegradable waste in landfills to mitigate climate gas production. To be able to stabilize source separated waste before landfilling a constructed biocell has been tested during a four year period. The research is part of a pilot project organized by Avfall Norge. A total amount of 12000 tons of waste from both industry and households were embedded in the biocell. Before loading, the waste fractions were characterized both in macro and micro scale. Anaerobic testing in lab scale documented the methane potential in different waste fractions. Especially car fluff contained toxic components which suppressed biodegradation. To avoid greenhouse gas leakage the biocell was constructed as a closed system with synthetic capping and gas wells coupled to a compressor. While the biogas was flared the leachate was collected and recycled. Leachate contains both nutrients and DOC which is supposed to increase the biological activity. During the first part of the test period the BOD/COD was above 0.5 before it declined. In addition both inorganic and organic environmental harmful components were analyzed in the leachate. Levels of heavy metal decreased during treatment. The methane production was detected on-line with IR. Both the production and gas phase concentration varied during the test period. A total of five gas wells were positioned at different levels in the biocell. Only one of them produced biogas for a considerable period. This presentation will focus on biocell construction and waste degradation related to variation in leachate constituents as a function of time.
\end{abstract}

\section{KEYWORDS}

Biocell, Anaerobic digestion, Waste, Methane, Leachate, Nutrient recycling.

\section{INTRODUCTION}

Waste management is changing in Norway. Traditionally dumps of degradable waste are not allowed if the TOC content in the waste is above $10 \%$. In addition a landfill tax has to be paid if the TOC measures between 5 and $10 \%$. Handling of waste is now focused on material resources and energy. Especially incineration requires high investments in technology and infrastructure. For biodegradable waste the microbes provides different solutions; aerobic production of 
compost materials or anaerobic digestion to produce methane and wet fertilizers. A biocell technique achieves the combination of landfilling and anaerobic digestion. It may also be seen as an improved landfilling, with respect to leachate treatment and biogas collection.

Avfall Norge started a project in 2008 to clarify the potential for biocell treatment of biodegradable waste in Norway. The main purpose of the project was to convert organic material into methane $\left(\mathrm{CH}_{4}\right)$ and stabilize the residual masses before landfilling. The project included five waste companies composing different biocells with different waste contents. This presentation focuses on biocell design and waste processing at GLT-Waste. According to the plan excavation of the cell should be accomplished in 2013.

\section{BIOCELL CHARACTERISTICS}

Both biogas collection and leachate recirculation are important design parameters. Regarding water balance the biocell should be a closed system and the biogas should be handled in an environmentally acceptable manner and not leak into the atmosphere. To meet these requirements the biocell was constructed on the top cover of an old landfill site that was shut down in 2001. To avoid settlement, the top cover below the biocell was strengthened with a $0.5 \mathrm{~m}$ layer of crude asphalt. A cross section of the biocell is illustrated in Figure 1. The total height and width of the construction is respectively 5.5 and 30 meters. The length is $80 \mathrm{~m}$ which gives the total volume of approximately $10000 \mathrm{~m}^{3}$. Important design parameters are illustrated in Figure 1.

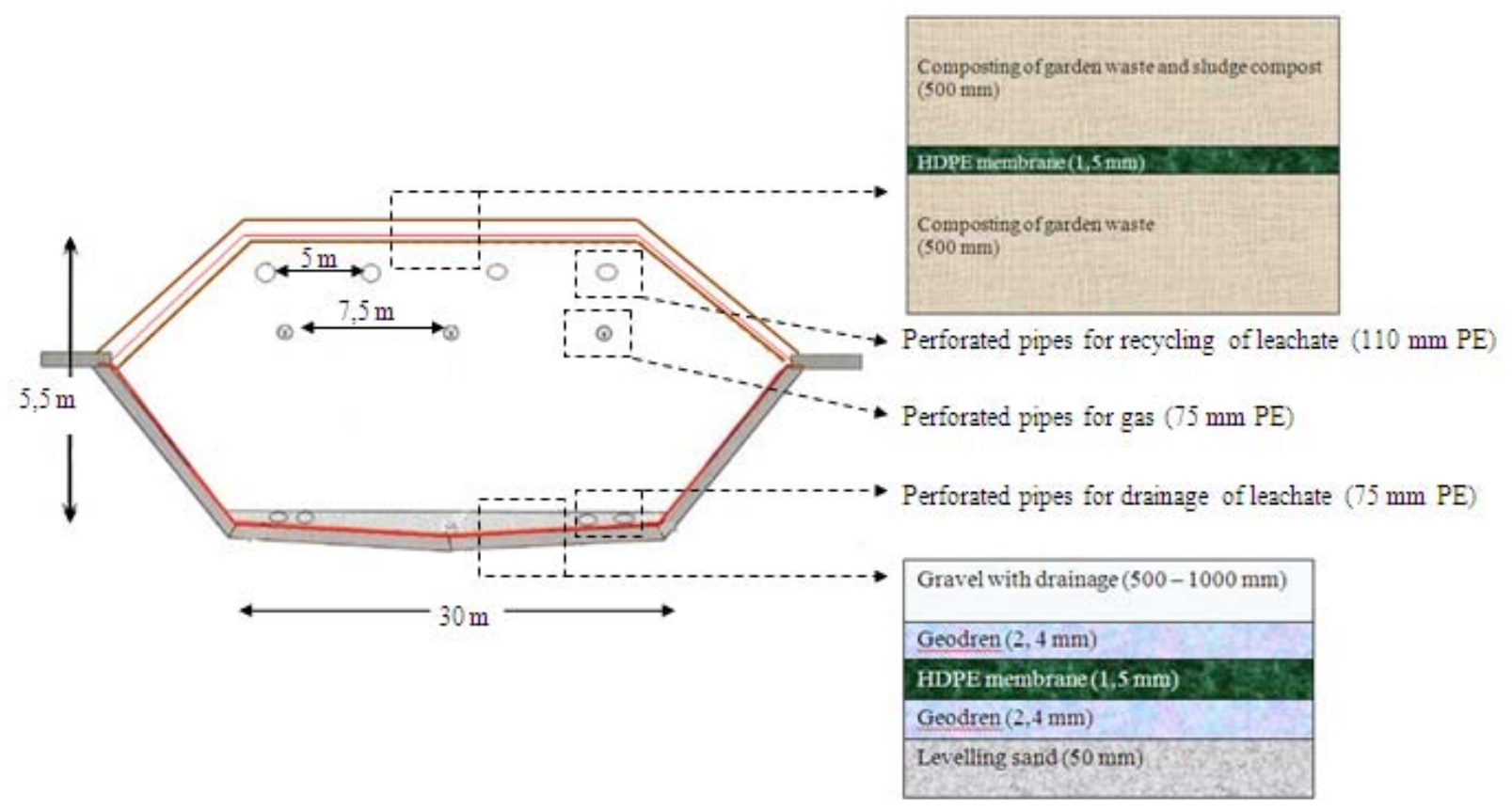

Figure 1. Schematic design of a biocell. 


\subsection{Liner system}

The waste material was enveloped in a synthetic barrier of HDPE with a thickness of $1.5 \mathrm{~mm}$. According to Qian et.al HDPE is the most chemically resistant of all geomembranes [i]. To protect the membrane and increase the slope stability a textile liner covered both sides of the HDPE at the bottom (Geodren $2.4 \mathrm{~mm}$ ). The top sides were covered with soil containing organic material $(0.5 \mathrm{~m})$ to boost the degradation process before the HDPE membrane was seamed. The liner head was covered with soil containing stable sludge compost to protect the liner from weathering.

\subsection{Leachate collection and recirculation system}

Leachate collection pipes are $75 \mathrm{~mm}$ (d) PE perforated tubes. They lay in a drainage layer of 500$1000 \mathrm{~mm}$ gravel with a particle size in the range of 16-22 $\mathrm{mm}$ in two pairs on each long side of the biocell. The pipes are gathered to one gas well pr side, and connected to a blower with vacuum of -75 mbar, for extracting any biogas. Recirculation pipes are $110 \mathrm{~mm}$ (d) PE. To avoid clogging the recirculation tubes were perforated with a dimension of $8 \mathrm{~mm}$ for every $0.80 \mathrm{~m}$. Precipitation during cell loading and humidity in the waste material are the only water in the process. Approximately $350 \mathrm{~m}^{3}$ of the leachate has been handled at a waste water plant. The water balance has to be calculated at the end of the project and will be presented in the main project report.

\subsection{Gas collection and handling}

Three gas wells $(\mathrm{d} 75 \mathrm{~mm})$ are located approximately $1 \mathrm{~m}$ from the top of the cell. They are run in parallel at a distance of $7.5 \mathrm{~m}$ from each other as illustrated in Figure 1. The extraction wells are perforated with $8-10$ boreholes $(\mathrm{d} 8 \mathrm{~mm})$ each every meter. To be able to trap condensate each well are mounted with a $4 \%$ decrease and both gas and leachate are moving in the same direction. To prevent siphons due to bulk settlement of the biocell the extraction wells are mounted on CCA impregnated waste material (plank). This could however increase the concentration of $\mathrm{As}, \mathrm{Cr}$ and $\mathrm{Cu}$ in the leachate. Waste glass materials are used instead of gravel to avoid clogging of the extraction well. To extract the biogas a vacuum of approximately - 75 mbar is created by a blower. The gas wells are coupled to an auxiliary collector plant and both $\mathrm{CH}_{4}$ and $\mathrm{O}_{2}$ are measured individually in each pipe. The biogas are oxidised in a flare together with $\mathrm{CH}_{4}$ produced in the old landfill.

\subsection{Incoming waste and loading method}

An important goal in the project is to utilize a combination of waste that is representative for waste production in our region. A metal recycling plant utilizes a shredding facility to regain metal in our neighbourhood. Shredder residue, the resulting material from shredding of automobiles, large household appliances and other industrial items is especially interesting due to landfill banning and the wide variety of contaminants in the waste fraction. Both macro and micro scale characterization of the different waste materials have been done before loading the call. Representative sampling and preparation has been carried out before characterization as shown in Table 1.

Source separated household waste has been sampled and analyzed two times. This is due to a very high level of $\mathrm{Zn}$ in the first sample (Table 2). Also $\mathrm{Cu}$ and $\mathrm{Ni}$ were measured at much higher 
levels than in the second sample. This is also true for nutrients like $\mathrm{P}, \mathrm{Ca}$ and $\mathrm{K}$. It is interesting to evaluate the level of heavy metals in fluff. Both $\mathrm{Zn}, \mathrm{Cu}, \mathrm{Cr}$ and $\mathrm{Ni}$ are at a much higher level compared to the other waste fraction. This could explain the low bacterial activity during testing of $\mathrm{CH}_{4}$ production possibility (Figure 2). A composite sample containing all waste fractions was analyzed in the same way. High levels of both $\mathrm{Cu}$ and $\mathrm{Zn}$ were observed. The reason for this is possibly related to both fluff and industrial waste.

The landfill ban in Norway is related to the level of TOC in the waste fractions. None of the waste materials could be landfilled without a written authorization from the environmental government. The fluff material has the lowest TOC (15\%).

Table 1. Sampling and preparation of source separated waste fractions before characterization

\begin{tabular}{|c|c|c|c|c|c|}
\hline Material & $\begin{array}{c}\text { Household } \\
\text { waste }\end{array}$ & Industrial waste & Car fluff & $\begin{array}{c}\text { Household } \\
\text { waste }\end{array}$ & Biocell material \\
\hline $\begin{array}{l}\text { Primary } \\
\text { sample }\end{array}$ & $4420 \mathrm{~kg}$ & $2200 \mathrm{~kg}$ & $25140 \mathrm{~kg}$ & $5900 \mathrm{~kg}$ & $250 \mathrm{~m}^{3}$ \\
\hline Method & Quarters down & Quarters down & $\begin{array}{l}\text { Random } \\
\text { sampling of } \\
0.250 \mathrm{~kg} \text { aliquot } \\
\text { part-sample. } \\
\text { The total of } 138 \\
\text { samples }\end{array}$ & Quarters down & $\begin{array}{l}\text { Randomly } \\
\text { choose } 5 \mathrm{~m}^{3} \\
\text { with wheel } \\
\text { loader, mixed } \\
\text { and randomly } \\
\text { sample } 50 \mathrm{~kg}\end{array}$ \\
\hline $\begin{array}{l}\text { Secondary } \\
\text { sample }\end{array}$ & $2 \mathrm{~m}^{3}$ & $3 \mathrm{~m}^{3}$ & $34.5 \mathrm{~kg}$ & $1 \mathrm{~m}^{3}$ & $50 \mathrm{~kg}$ \\
\hline Churned & Yes & Yes & Yes & Yes & Yes \\
\hline Method & Quarters down & Quarters down & Homogenization & Quarters down & Quarters down \\
\hline Other & $\begin{array}{l}\text { Sorted out } 2 \\
\mathrm{~kg} \text { metal } \\
\text { before } \\
\text { shredding. } \\
\text { Homogenizati } \\
\text { on before } \\
\text { random } \\
\text { sampling. }\end{array}$ & $\begin{array}{l}\text { Sorted out } 11,5 \\
\text { kg metal before } \\
\text { shredding. } \\
\text { Homogenization } \\
\text { before random } \\
\text { sampling. }\end{array}$ & $\begin{array}{l}\text { Homogenization } \\
\text { after random } \\
\text { sampling. } 138 \\
\text { part-samples } \\
\text { homogenised to } \\
\text { one mix sample. }\end{array}$ & $\begin{array}{l}\text { Homogenization } \\
\text { before random } \\
\text { sampling }\end{array}$ & $\begin{array}{l}\text { Homogenization } \\
\text { before random } \\
\text { sampling. }\end{array}$ \\
\hline Sample size & $30 \mathrm{~kg}$ & $28 \mathrm{~kg}$ & $34.5 \mathrm{~kg}$ & $30 \mathrm{~kg}$ & $30 \mathrm{~kg}$ \\
\hline
\end{tabular}


Table 2. Waste caracterization (unit pr. dense weight)

\begin{tabular}{|l|l|c|c|c|c|c|}
\hline Analyze & Unit & $\begin{array}{c}\text { Household } \\
\text { waste }\end{array}$ & $\begin{array}{c}\text { Industrial } \\
\text { waste }\end{array}$ & $\begin{array}{c}\text { Car } \\
\text { fluff }\end{array}$ & $\begin{array}{c}\text { Household } \\
\text { waste }\end{array}$ & $\begin{array}{c}\text { Biocell } \\
\text { material }\end{array}$ \\
\hline Dw & $\%$ & 72.6 & 78 & 77.6 & 66.1 & 70.8 \\
\hline Loss on ignition & $\% \mathrm{pr}$ & 87 & 36.8 & 21.8 & 91.5 & 95 \\
\hline $\mathrm{Ca}$ & $\mathrm{g} / \mathrm{kg}$ & 73.8 & 137.3 & 155.8 & 8.8 & 18.2 \\
\hline $\mathrm{P}$ & $\mathrm{g} / \mathrm{kg}$ & 5.9 & 0.8 & 6.2 & 0.86 & 0.94 \\
\hline $\mathrm{Mg}$ & $\mathrm{g} / \mathrm{kg}$ & 3.6 & 19.6 & 30.3 & 0.63 & 3.10 \\
\hline $\mathrm{K}$ & $\mathrm{g} / \mathrm{kg}$ & 8.2 & 4.3 & 6.9 & 3.12 & 1.87 \\
\hline $\mathrm{Na}$ & $\mathrm{g} / \mathrm{kg}$ & 16.1 & 6.7 & 15 & 2.3 & 1.9 \\
\hline $\mathrm{S}$ & $\mathrm{g} / \mathrm{kg}$ & 9.9 & 5.3 & 26.9 & 1.56 & 2.7 \\
\hline $\mathrm{Cr}$ & $\mathrm{mg} / \mathrm{kg}$ & 20.5 & 54.2 & 160.5 & 12.1 & 48.4 \\
\hline $\mathrm{Mn}$ & $\mathrm{mg} / \mathrm{kg}$ & 31.8 & 84.7 & 1370.3 & 255 & 201 \\
\hline $\mathrm{Ni}$ & $\mathrm{mg} / \mathrm{kg}$ & 53.5 & 10.8 & 278.6 & 3.1 & 32.2 \\
\hline $\mathrm{Cu}$ & $\mathrm{mg} / \mathrm{kg}$ & 973.9 & 42.2 & 4945.9 & 76 & 1855 \\
\hline Zn & $\mathrm{mg} / \mathrm{kg}$ & 440793 & 2531 & 21487 & 309 & 1518 \\
\hline Org-N & $\%$ & 2.63 & 1.25 & 0.74 & 1.9 & 1.3 \\
\hline $\mathrm{NH} 4-\mathrm{N}$ & $\mathrm{g} / \mathrm{kg}$ & 0.4 & $\mathrm{n} . \mathrm{d}$ & 0.3 & 0.7 & 0.3 \\
\hline NO3-N & $\mathrm{mg} / \mathrm{kg}$ & 3.1 & 4.7 & 1.6 & $\mathrm{n} . \mathrm{d}$ & $\mathrm{n} . \mathrm{d}$ \\
\hline NO3 \& NO2-N & $\mathrm{mg} / \mathrm{kg}$ & & & & 26.7 & 4.9 \\
\hline TOC & $\%$ & 49.68 & 20.83 & 14.97 & 37.6 & 19.3 \\
\hline C/N & & 18.9 & 16.7 & 20.2 & & \\
\hline Tot-N & $\mathrm{g} / \mathrm{kg}$ & 26.7 & 12.5 & 7.7 & 2 & 1.3 \\
\hline Cellulose & $\mathrm{g} / \mathrm{kg}$ & 358.2 & 137.4 & 106.9 & 418 & 341 \\
\hline ADF & $\mathrm{g} / \mathrm{kg}$ & 427.5 & 202.3 & 147.7 & 501 & 494 \\
\hline Lignin & $\mathrm{g} / \mathrm{kg}$ & 69.3 & 64.9 & 40.8 & 83 & 153 \\
\hline Volume weight & $\mathrm{g} / \mathrm{L}$ & 115.8 & 304.2 & 535.2 & 73.4 & 116 \\
\hline & & & & & & \\
\hline & & & & & & \\
\hline
\end{tabular}

n.d (not detected)

Together with micro scale analysis of the waste the $\mathrm{CH}_{4}$ potential was also measured in lab scale (Figure 2). The samples were spiked with microbes to boost biogas production. After only two days a significant production of $\mathrm{CH}_{4}$ was detected. The highest production was observed in the second sample of household waste. It is very interesting to observe the negative potential in the fluff material, and very likely the high concentration of heavy metals have a toxic effect on the environment. The composite sample has the lowest production potential. 
Linnaeus ECO-TECH 2012

Kalmar, Sweden, November 26-28, 2012

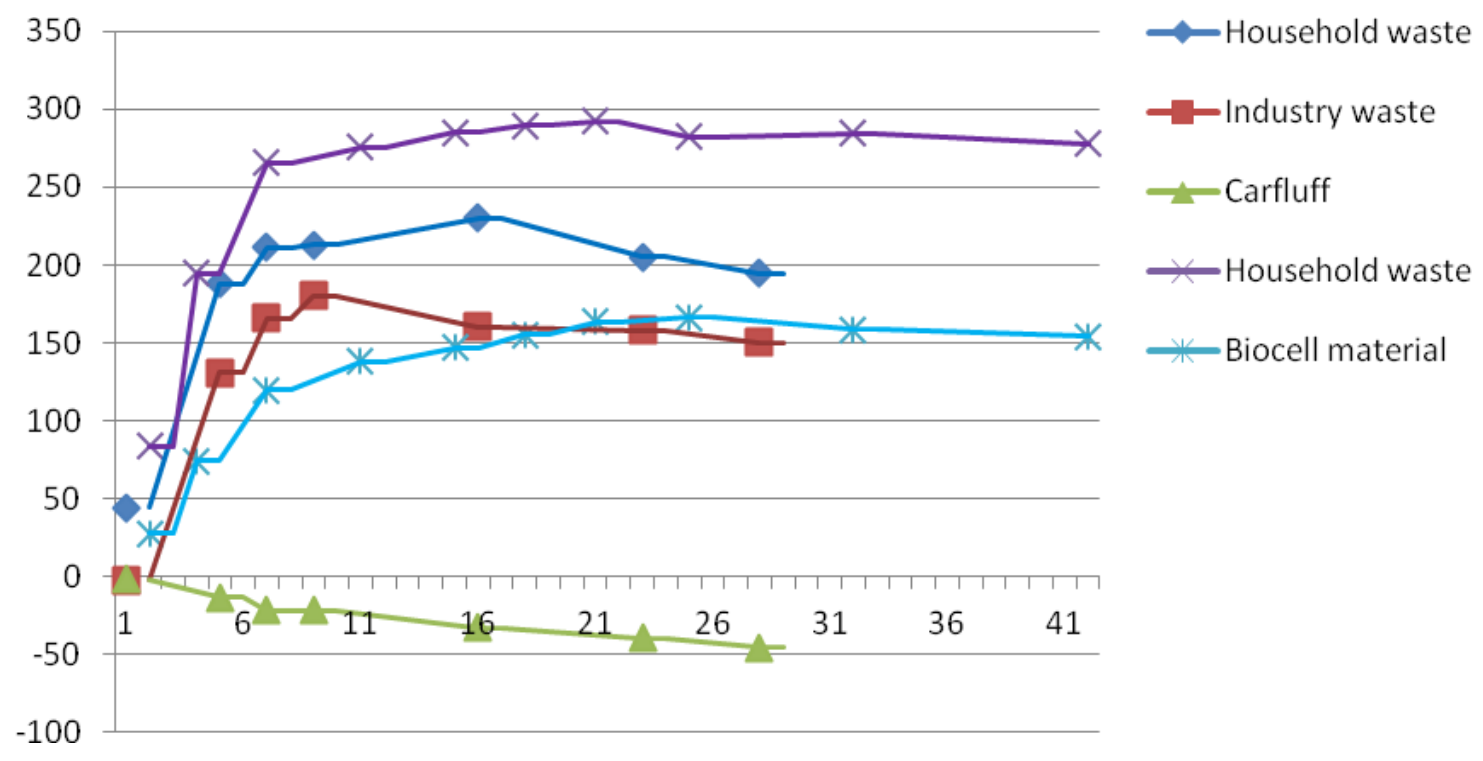

Figure 2. Methane productions in lab scale ( $\mathrm{Nml} \mathrm{CH}_{4} / \mathrm{g} \mathrm{VS}$ ) as a function of time (days)

Before loading the biocell, a kind of pre-treatment was done to decrease the heterogeneity of the waste material. A compaction roller of 40 tons knead the waste with repeated passages of the roller. A front loader transported the waste into the biocell. Due to possible danger of penetrating the membrane or other installations with its feet on the roller the waste material was not mechanically compressed during packing with waste. Above the waste a layer of compost material was added to boost degradation and protect the membrane.

\section{EXPERIMENTAL}

\subsection{Monitoring programs}

A monitoring program for both leachate and biogas was developed for all five waste companies in the main project. To be able to compare results from different biocells it is import that parameters and sample frequencies are in accordance with the main project. The leachate program was divided into a monthly and quarterly program. Except for $\mathrm{NH}_{4}{ }^{+}-\mathrm{N}$ the monthly program included only sum parameters. To be able to follow the degradation process by analyzing the water phase, organic acids are very important indicators. Included in the quarterly program are also $\mathrm{SO}_{4}{ }^{2-}$ and nutrients like $\mathrm{P}$ and $\mathrm{N}$ (Table 3).

Table 3. Monitoring program leachate

\begin{tabular}{|l|l|}
\hline Program & Parameter \\
\hline Monthly & $\mathrm{pH}, \mathrm{mS} / \mathrm{m}, \mathrm{COD}, \mathrm{BOD}, \mathrm{TOC}, \mathrm{NH}_{4}{ }^{+}-\mathrm{N}$ \\
\hline Quarterly & Org. acids, $\mathrm{SO}_{4}{ }^{2-}, \mathrm{SS}$, Tot-P, Tot-N, Tot-S \\
\hline
\end{tabular}


The monthly leachate analysis was conducted by instrumentation from WTW (pH and conductivity) and NanoColor UV/VIS Spectrophotometer from Macherey-Nagel. This is not an accredited analysis so control samples were analyzed at external laboratories. All analyses in the quarterly program were analyzed by Mjøslab. Especially because of the high content of heavy metals in the car fluff material it was necessary to follow the metal concentrations in the leachate. These parameters were only established for the biocelle at GLT Waste, at a yearly basis. The results are presented in Figure 6.

The quality of biogas was detected on-line by local instruments mounted in the auxiliary collector plant. $\mathrm{CH}_{4}$ was detected by a Simrad GD10 IR gas detector from Simrad Optronics and $\mathrm{O}_{2}$ was detected by a TXgard Plus OX from Crowcon. In addition an IR-instrument (GA 94) from Geotechnical Instruments Inc. was used to control reproducibility of the stationary instrumentation. Also $\mathrm{CO}_{2}$ was detected by GA 94 .

A main goal for this project is to test and document a low technological method to stabilize waste which will leak $\mathrm{CH}_{4}$ into the atmosphere in an ordinary landfill. Therefore it is really important that biogas is handled without affecting the climate. The extraction efficiency and top cover are important variables. A possible leak trough the top cover was documented utilizing direct measurement and static flux chambers. $\mathrm{CH}_{4}$ detection was done either by the laser detector (TDL500) from Geotechnical instruments or the IR-instrument GA 94.

\section{RESULTS AND DISCUSSION}

\subsection{Leachate quality}

A detailed description of the degradation process focusing on both production of short chain fatty acids and both $\mathrm{CH}_{4}$ and inorganic $\mathrm{S}^{2-}$ was done by Christensen et.al [ii]. Before a stable production of biogas it is expected to observe high concentrations of both BOD and COD. A main constituent in BOD is fatty acids. The development of both BOD and COD can be seen in Figure 3. The project started in 2009 and already in the autumn of 2009 the BOD concentration decreased. If we look at the fatty acid concentrations the variation in concentration follows the same profile (Figure 4). 


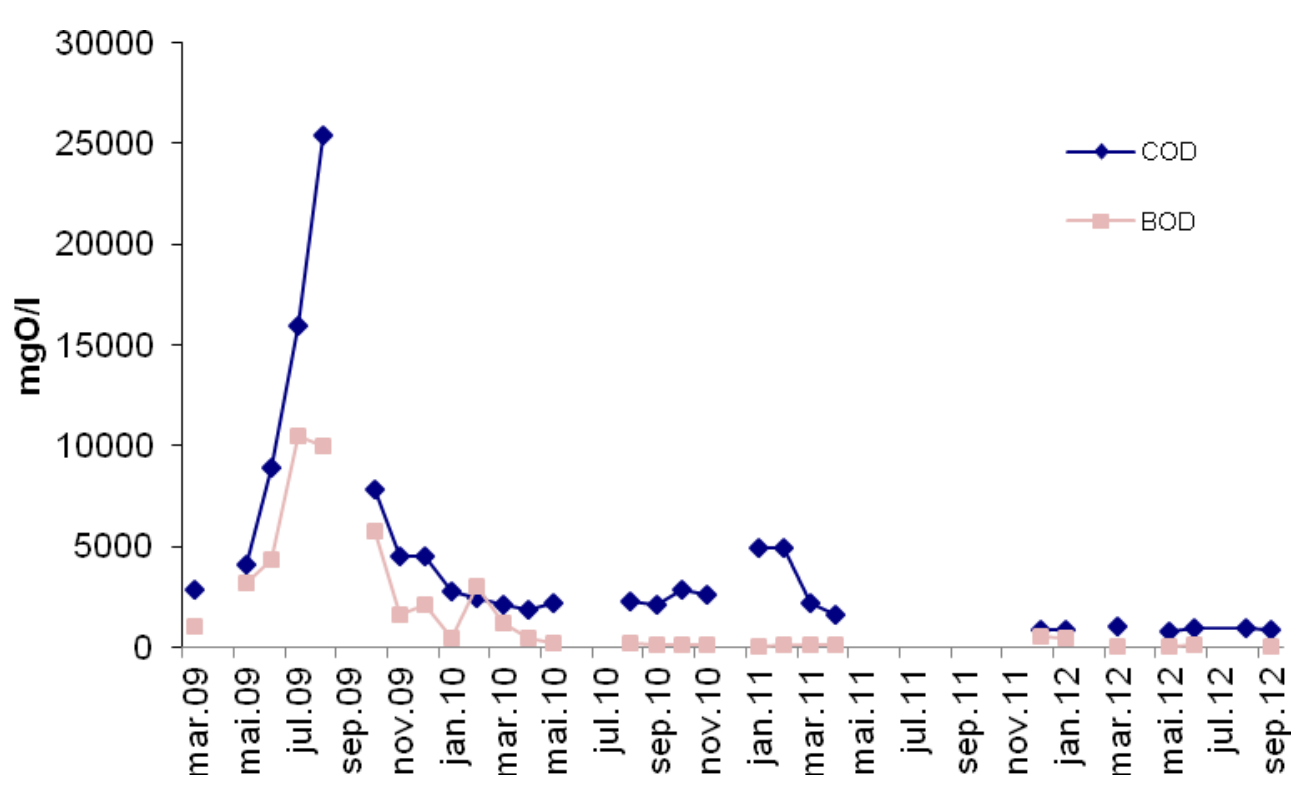

Figure 3. Levels of BOD and COD as a function of time of treatment

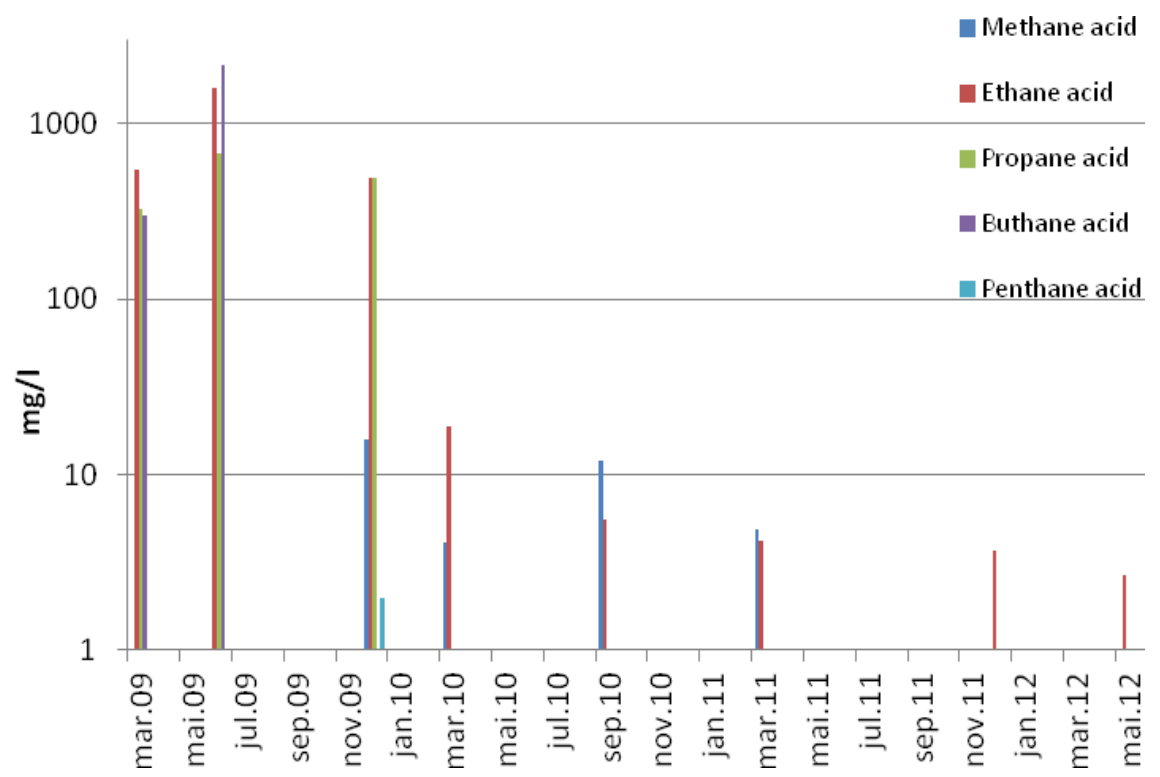

Figure 4. Levels of organic acids as a function of time of treatment

When the decrease of organic acids occurs it is expected that the production of $\mathrm{CH}_{4}$ starts. Due to detection problems this situation is not so distinct. The variation of $\mathrm{SO}_{4}{ }^{2-}$ is also a function of anaerobic conditions. In an oxidative environment the sulphur is at the highest level of oxidation. When the $\mathrm{O}_{2}$ level decreases the sulphur is reduced to $\mathrm{S}^{2-}$. As well known cat ions of heavy metals have a very low solubility combined with $\mathrm{S}^{2-}$. A very dramatic decrease in concentration of $\mathrm{SO}_{4}{ }^{2-}$ was observed in the autumn of 2009 short after the membrane was seamed. The leakage 
of cat ions is not distinct but a significant decrease is however observed in Figure 6. The concentration of $\mathrm{Zn}$ in the waste load was very high in some of the fractions (Table 2). In December 2009 the concentration was $500 \mathrm{ug} / \mathrm{l}$ in the leachate. During the 4-year period the concentration was reduced by 5 times less. The initial concentration of $\mathrm{Cr}$ was not at the same level (350 ug/l) but the concentration at January 2012 was comparable to $\mathrm{Zn}$.

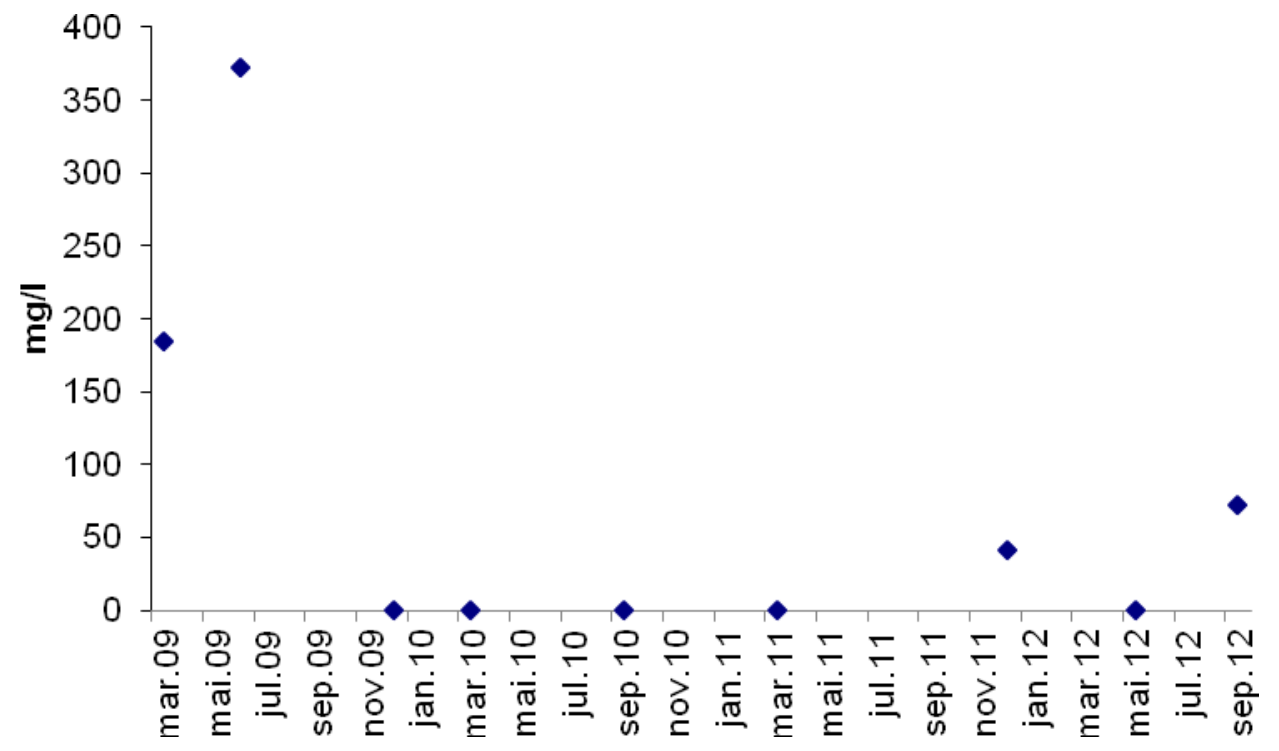

Figure 5. Levels of $\mathrm{SO}_{4}{ }^{2-}$ as a function of time of treatment

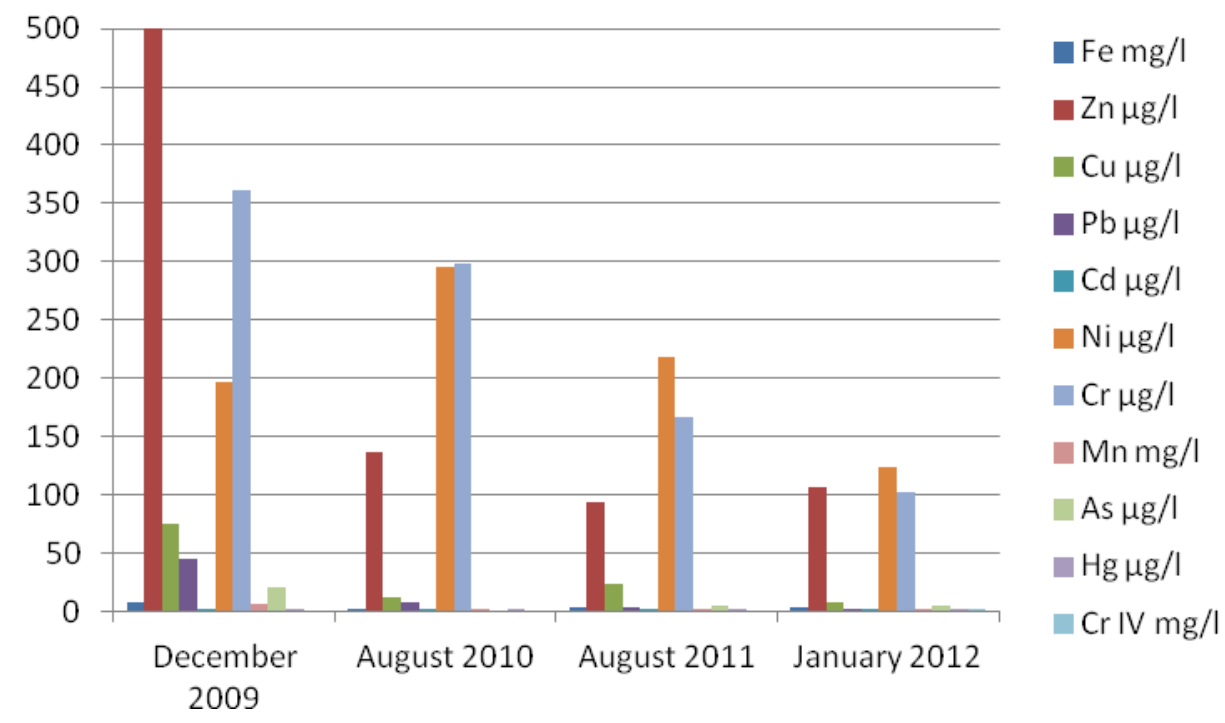

Figure 6. Levels of heavy metals as a function of time of treatment 


\subsection{Biogas quality and production}

Before closing the biocell, temperature measurements documented a high degree of biological activity in the waste material. Temperatures as high as $50{ }^{\circ} \mathrm{C}$ were observed. Using the IRinstrument at the top of the heap measured $\mathrm{CH}_{4}$ in the range of 0.3 to $5 \%$. Measuring at the end of gas and leachate tubings documented concentrations as high as $40 \%$ of $\mathrm{CH}_{4}$. After closing the biocell the transportation tubings were coupled via the condensation trap to the auxiliary collector plant. A constant pressure of approximately $-75 \mathrm{mbar}$ was used to extract the biogas. The five gas wells are numbered \#7 - \#11. In Figure 7 the biogas production rate is illustrated in the 5 extraction wells. A great degree of variation could be seen in the whole period from 2009 until summer 2012. As already mentioned the whole plant suffered from serious technical problems in 2011. After a new blower was installed one of the extraction pipes (\#7) has delivered biogas at a rate of approximately $5 \mathrm{Nm}^{3} / \mathrm{h}$ in a period of six months.

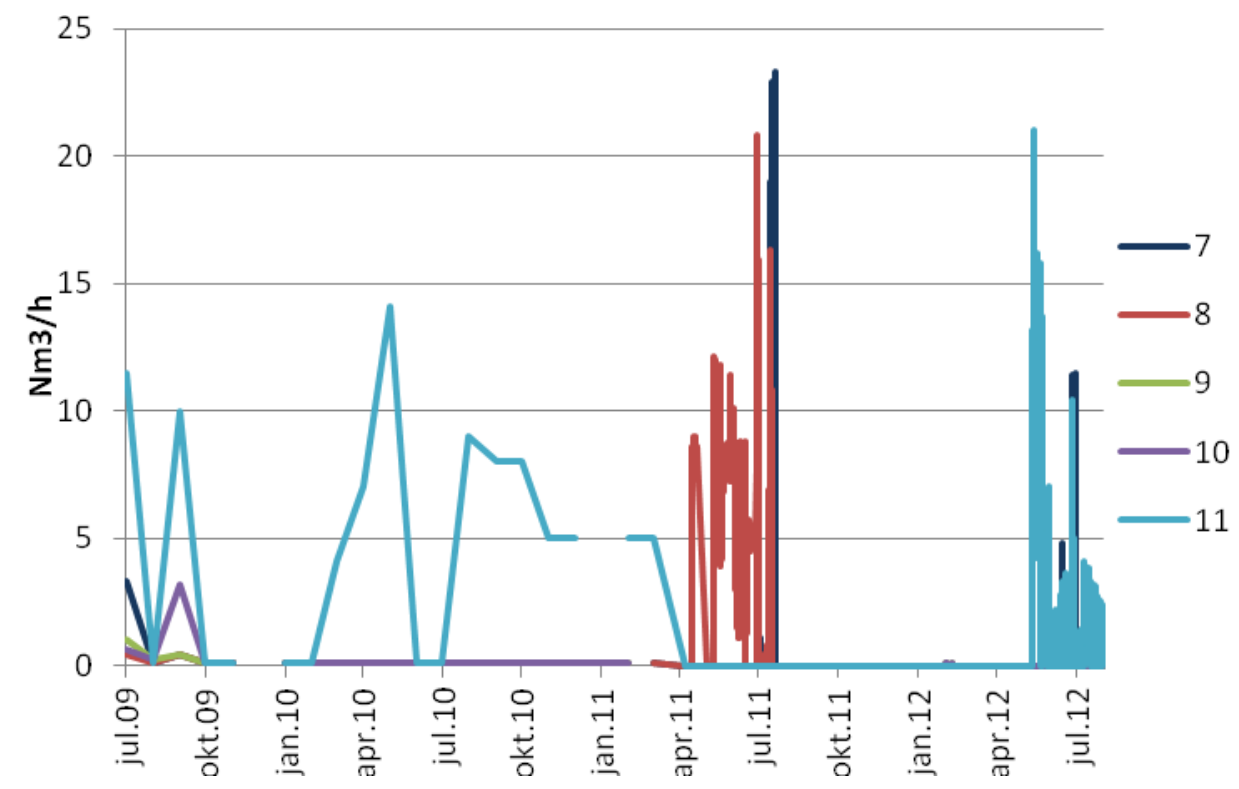

Figure 7. Amount of biogas extracted from the biocell

In the beginning of treatment, the amount of biogas collected and treated was lower than expected. One possible reason could be leakage of toxic elements from the fluff material. Another theory could be the amount of moisture. High water concentration combined with plastic waste could form water pockets in the biocell. This situation could mitigate the production of methane. The total amount of biogas extracted is stated in Table 4. Two of the extraction wells produced less than $11 \mathrm{Nm}^{3}$. The total amount of biogas produced was between less $19000 \mathrm{Nm}^{3}$. 


\begin{tabular}{|l|c|c|c|c|c|c|}
\hline Gas well & $\# 7$ & $\# 8$ & $\# 9$ & $\# 10$ & $\# 11$ & Total \\
\hline $\mathrm{Nm}^{3}$ & 4132 & 10164 & 8 & 11 & 4361 & 18676 \\
\hline
\end{tabular}

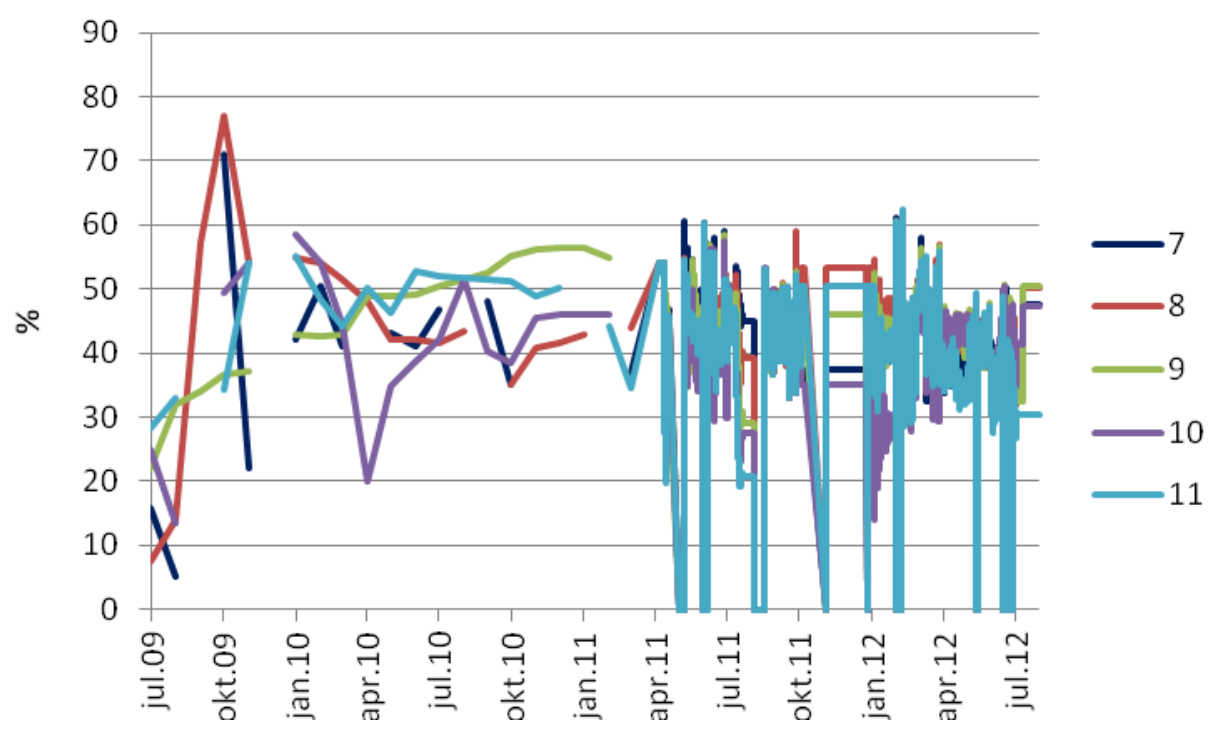

Figure 8. Contents of $\mathrm{CH}_{4}$ in the biogas

During the project period the concentration of $\mathrm{CH}_{4}$ has been above $30 \%$ (Figure 8) which is comparable to a traditional landfill. Gas quality and extraction amount correlates as can be seen in gas well nr. 8.

\subsection{Capping quality}

To reduce methane leakages during landfilling was the main reason for banning biodegradable waste in traditional landfills. Therefore it is very important to be able to degrade unstable waste in a controllable manner. Documentation of capping quality has been done both during direct measurements and via static flux chamber using a TDL-500 laser instrument. Before capping, the maximum concentration of $\mathrm{CH}_{4}$ was $50000 \mathrm{ppm}$. After capping we were not able to measure biogas above the quantification limit $(\mathrm{LOQ}=10 \mathrm{ppm})$

\section{CONCLUDING REMARKS}

During the 4-year period the biocell has settled approximately $1.8 \mathrm{~m}$ and it is no doubt that the biogas production is significant. The compaction of waste also influence on technical installations like coupling between gas wells, transportation tubing and systems for circulation of water phase. The leachate in itself is also corrosive and contains high concentrations of $\mathrm{Fe}^{2+}$ which could oxidize to $\mathrm{Fe}^{3+}$ when the $\mathrm{O}_{2}$ level increases. The solubility of $\mathrm{Fe}^{3+}$ is much less compared to $\mathrm{Fe}^{2+}$. Clogging of pipes for leachate and biogas could influence the degradation process. The 
circulation pump for water phase has also been damaged due to precipitation in the pump housing.

Extraction of biogas is also problematic. Condensation and water trapping is a major challenge. During a six month period the extraction system was out of order. In April 2012 a new blower was installed and since then a stable extraction of biogas has been possible.

Is it possible to use a low technological anaerobic reactor to produce $\mathrm{CH}_{4}$ under controllable conditions and be able to produce waste with acceptable stability? The monitoring program has been in accordance to what should be expected in an anaerobic process. Excavation and characterization of the biocell residue may give the answer.

\section{ACKNOWLEDGMENT}

We thank Kristian Ohr from Asplan Viak, the project manager in the main project, and Henrik Lystad from Avfall Norge, responsible for the main project. We also want to thank Detox for analyzing the waste fractions. Trond Skaug and Ivar Svastuen from GLT-Waste deserve thanks for all practical help from the beginning with constructing the biocell, to handling the challenges that occurred during the treatment period.

\section{REFERENCES}

i. X. Qian, R. M. Koerner, D. H. Gray, "Geotechnical aspects of landfill design and construction", Prectice Hall Inc., New Jersey, (2002), 710 pages

ii T. H. Christensen, R. Cossu, R. Stegmann (Ed.), "Landfilling of waste: BIOGAS", E \& FN

Spon, Lomdon, (1996), 813 pages 